\title{
CRITICAL ANALYSIS OF STRATEGIES FOR PM REDUCTION IN URBAN AREAS
}

\author{
Gabriela IONESCU ${ }^{1}$, Tiberiu APOSTOL ${ }^{2}$, Elena Cristina RADA ${ }^{3}$, Marco \\ RAGAZZI $^{4}$, Vincenzo TORRETTA ${ }^{5}$
}

\begin{abstract}
This paper presents an overview of practical strategies that can be adopted for reducing the particulate matter concentration in urban areas. Each strategy is analyzed taking into account the latest results of the scientific literature. A discussion useful for pointing out some problems to be solved for their correct adoptions completes the paper.
\end{abstract}

Keywords: atmospheric pollution, particulate matter, strategies, urban area

\section{Introduction}

The globalization and rapid industrial development of urban cities has conducted to notable modifications on air quality. Environmental and social questions have been raised on air pollution. Among them, the particular matter (PM) may be the air pollutant that has the most commonly known environmental global effects. In the last two decades concerns on particulate matter concentration values in urban areas led to a number of researches on this type of pollutant $[1,2]$. According to Amato et al., [3] the atmospheric particulate matter (PM) is a complex mixture of components arising from a number of emission sources (anthropogenic, but also natural) and atmospheric processes (secondary PM) which have a variable diameter in the range $0.01 \mu \mathrm{m}-100 \mu \mathrm{m}$. The differences and amount of PM is mainly influenced by complex interactions of the source characteristics with the geography, season and short-term meteorology of the site.

\footnotetext{
${ }^{1} \mathrm{PhD}$, Dept. of Energy Production and Use, POLITEHNICA University of Bucharest, Romania, e-mail: gabriela_ionescu@ymail.com

${ }^{2}$ Prof., Dept. of Energy Production and Use, POLITEHNICA University of Bucharest, Romania, e-mail: tiberiuaposto180@gmail.com

${ }^{3} \mathrm{PhD}$, Dept. of Civil Environmental and Mechanical Engineering, University of Trento, Italy, email: elena.rada@ing.unitn.it

${ }^{4}$ Prof., Dept. of Civil, Environmental and Mechanical Engineering, University of Trento, Trento, Italy, e-mail: marco.ragazzi@ing.unitn.it

${ }^{5}$ Prof., Dept. of Science and High Technology, University of Insubria, Italy, e-mail:

vincenzo.torretta@uninsubria.it
} 
Depending on their aerodynamic diameter $\left(a_{d}\right)$, the PM is divided into three main categories:

$>$ coarse fraction ranging from $2.5 \mu m \leq a_{d} \leq 10 \mu m$ is produced by mechanical processes such as erosion, grinding or suspension and may include marine aerosols, pollen and dust resulting from agricultural processes, roads etc..;

$>$ fine fraction ranging from $0.1 \mu \mathrm{m} \leq a_{d} \leq 2.5 \mu \mathrm{m}$ is produced by means of clot particles ultrafine, or for heterogeneous nucleation;

$>$ ultrafine fraction $-a_{d} \leq 0.1 \mu \mathrm{m}$ is produced by homogeneous nucleation vapor $\mathrm{SO}_{2}, \mathrm{NH}_{3}, \mathrm{NO}_{\mathrm{x}}$ and products combustion which form new particles by condensation and grow for coagulation.

Measurements of fine particulate matter $\left(\mathrm{PM}_{10}\right.$ and $\left.\mathrm{PM}_{2.5}\right)$ have become an interest in air quality studies, mainly because they are associated with numerous health effects. Many epidemiological studies have demonstrated the toxicity of certain pollutants and the relationship between their emission and increased mortality and hospitalization $[4,5]$. Worldwide, about $3 \%$ of respiratory infection, $5 \%$ of cardiopulmonary and $8 \%$ of lung cancer deaths are attributed to PM exposure [6]. An investigation made in Arizona, where the $\mathrm{PM}_{10-2.5} / \mathrm{PM}_{10}$ average ratio is about 0.7 , has observed associations between $\mathrm{PM}_{10}, \mathrm{PM}_{10-2.5}$ and total mortality [7]. The same association can be made with the study made in California (a desert region) suggesting a mortality effect of $\mathrm{PM}_{10}$ in a region where $\mathrm{PM}$ mass is dominated by coarse mode aerosols [8]. L. Perez et al., $[9,10]$ have shown the association between significant levels of coarse PM resulted from human activity and daily mortality in Barcelona (Spain) and demonstrated the same effect of the particle from the Saharan dust. Over more, the cardiovascular and cerebrovascular mortality were associated with increased levels of coarse fractions $\left(\mathrm{PM}_{1}\right.$ and $\mathrm{PM}_{2.5-10}$ ) [10]. It can be conclude that in dried-up regions the mortality increases on coarse PM presence.

In Europe the standards on ambient air quality and cleaner air is covered by Directive 2008/50/EC where the annul amount of $\mathrm{PM}_{2.5}$ cannot exceed $25 \mu \mathrm{g} / \mathrm{m}^{3}$ and $40 \mu \mathrm{g} / \mathrm{m}^{3}$ for $\mathrm{PM}_{10}$ [11]. In 2013 the Environmental Protection Agency (EPA) has lowered the allowable average concentration of certain PM with $20 \%$ respect to 2006 making it more drastic in comparison with the European standard. The new annual limit imposed for the $\mathrm{PM}_{2.5}$ concentration is $12 \mu \mathrm{g} / \mathrm{m}^{3}$ (primary) and $15 \mu \mathrm{g} / \mathrm{m}^{3}$ (secondary), annual means, averaged over 3 years [12]. Recent studies in Europe have shown that $\mathrm{PM}_{10}$ levels increase from natural to kerbside sites. Especially in urban and kerbside stations, $\mathrm{PM}_{10}$ levels are above the EU annual $\mathrm{PM}_{10}$ standard for 2010 [14].

In the forthcoming years, the meteorological conditions and smoke events might increase due to the air pollution in relation with climate change. In this context the current paper points out the latest practical and sustainable strategies 
for PM reduction that have become a human health and environmental future necessity.

\section{Sources of PM emissions}

The causes of air pollution episodes include various factors, e.g., emissions, local and synoptic-scale meteorological conditions, topography and atmospheric chemical processes $[15,16,17]$. The relative importance of such factors is dependent on the geographical region, its surrounding emission source areas and the related climatic characteristics, as well as the season of the year $[18,19]$. The produced PM can be divided in two main categories: primary (is the sum of the filterable and the condensable PM) and secondary PM (are particles that form through chemical reactions in the ambient air after dilution and condensation have occurred and generally belonged to the submicron $\mathrm{PM}_{1.0}$ mode). Therefore the secondary $\mathrm{PM}$ formed include precursor such as Volatile Organic Compounds (VOC), ammonia, $\mathrm{SO}_{2}$ and $\mathrm{NO}_{\mathrm{x}}$. In the emission inventory the secondary PM are not reported, only the precursor emissions.

Several studies have shown the mineral origin of $\mathrm{PM}_{10}$ and its silicates, carbonates, oxides and phosphates components which are more present in the $\mathrm{PM}_{2.5-10}$ (coarse) fraction rather than in $\mathrm{PM}_{2.5}$ (fine) particles [20,21,22]. Still, the mechanical abrasion of crustal materials which produces the amount $\mathrm{PM}_{2.5}$ fraction may be notable to the ecosystem [23]. A study conducted in six urban sites from Europe revealed the major components in $\mathrm{PM}_{2.5}$ were carbonaceous compounds $(\mathrm{POM}+\mathrm{EC})$, secondary ions and $\mathrm{SS}$, whereas those in $\mathrm{PM}_{2.5-10}$ were soil derived compounds, carbonaceous compounds, SS and nitrate. All the measured and estimated components together accounted for $79-106 \%$ of $\mathrm{PM}_{2.5}$ and $77-96 \%$ of $\mathrm{PM}_{2.5-10}$ [24].

The primary PM is generated from industrial activities of fossil fuels in cogeneration plants, in diesel vehicles, in the residential sector but also from industrial processes in forms of $\mathrm{PM}_{2.5}$ fines. The fine particles resulted from the fossil fuel combustion contain $\mathrm{As}, \mathrm{Be}, \mathrm{Cd}, \mathrm{Cr}, \mathrm{Co}, \mathrm{Pb}, \mathrm{Mg}, \mathrm{Ni}, \mathrm{Zn}$ and $\mathrm{Se}$. The traffic-related source of PM concentration is given by road surface wear, tyre and brake wears. In 2005, Hueglin et al. studied trace elements from rural traffic sites and concluded that concentrations of $\mathrm{Ba}, \mathrm{Cu}, \mathrm{Fe}, \mathrm{Mo}, \mathrm{Mn}$ and $\mathrm{Sb}$ from brake wear traces gradually decrease from kerbside to urban background, near-city and rural sites [25]. Earlier studies reported an important concentration of $\mathrm{Zn}, \mathrm{Cd}, \mathrm{Co}, \mathrm{Cr}$, $\mathrm{Cu}, \mathrm{Hg}, \mathrm{Mn}, \mathrm{Mo}, \mathrm{Ni}$, and $\mathrm{Pb}$ from tyre wear [26, 27].

The traffics related particles, which prevail on non-desert dust days, have more toxic effects than the ones originating from long-range transport, such as the Sahara dust. 
Looking over the European situation, as compared to Central Europe, the urban areas of Southern Europe are sensibly more enriched in suspended $\mathrm{PM}_{10}$ mineral matter due to the intensive deposition of non-vehicular related dust on the pavement due to African dust outbreaks or construction/demolition may contribute decisively to supplement the mineral load over roads in Southern Europe. This difference is contribution to the PM levels of crustal components which can may be attributed largely to the higher dust accumulation and resuspension effect during dry conditions in the southern EU countries, whereas higher rainfall in the central EU countries may help to clean the road dust from streets [3].

Although few researches have been made on the particles resulted from small-scale combustion utilities (domestic boiler or small residential) [28], it is considered that these type emissions affect the PM load in the coarse $\mathrm{PM}_{10}$ 2.5 mode. The particle mass can be significantly influenced by the wind-blown soil and re-suspended street dust that are present also in the coarse particle fraction [29]. The $\mathrm{PM}_{2.5} / \mathrm{PM}_{10}$ ratios can varies from 0.4 up to 0.7 depending on site analyzed.

Taking into account the secondary particles, in Europe the annual $\mathrm{PM}_{10}$ and $\mathrm{PM}_{2.5}$ concentrations are mainly affected by the regional aerosol background. As for chemical composition, Putaud et. al., demonstrated that organic matter appears more often as the major component of both $\mathrm{PM}_{10}$ and $\mathrm{PM}_{2.5}$, with the exception of natural and rural background sites, where sulphate contribution appear to be much greater. As for chemical composition, the organic matter appears more often as the major component of both $\mathrm{PM}_{10}$ and $\mathrm{PM}_{2.5}$, with the exception of natural and rural background sites, where sulphate contribution appear to be much greater [29].

The origins and sources of emission from long-range transport (LRT) and regional transport (RT) from local pollution (LP) could be distinguished. The Juda-Rezler et. al., reported, in Central Eastern European urban areas, that the high winter episodes of $\mathrm{PM}_{10}$ are for a large part caused by several anthropogenic emission processes that imply LRT, RT or LP sources, unfavorable synoptic-scale (anti-cyclonic circulation) and local meteorological conditions (very low temperature, low wind speeds, surface layer inversions) are also responsible for the occurrence of air pollution events [30]. The latter causes are completed by coal or wood combustion in cogeneration plants, but also the unfavorable winter (weather) conditions that increase the traffic emissions.

Due to the internal combustion engine, cars emit mostly fine and ultrafine particles. Aarnio et al., [31] and Niemi et al., [32] concluded that emissions from tyre and brake wear and also the resuspension of dust from the road surface as vehicular non-exhaust sources, represent one of the most important sources of air pollution at intersection sites. Note that if LP and RT sources are emitting a 
different level of PM concentrations, therefore the transboundary LRT particles can represent a source of episodic pollution caused by transnational PM migration. An investigation made in southern Finland pointed out the value of $\mathrm{PM}_{2.5}$ is usually exceeded in this area due to LRT of pollutants from Eastern Europe. The study highlighted that the investigated LRT episodes were caused by emissions not only from open biomass burning, but emissions from ordinary anthropogenic sources (e.g. from energy production, traffic, industry and wood combustion) in Eastern Europe also cause significant episodes. It should be pointed out that emissions from agricultural waste burning and wildfires conduct to air pollution on large areas, especially in warm and dry periods of the year (late spring and summer) even at the distance over $1000 \mathrm{~km}$ from the fire areas $[31,32]$.

In his latest work Srimuruganandam et. al., [14] presented the PM contribution in Chennai, India from diesel exhaust, gasoline exhaust, paved road dusts, brake lining dusts, brake pad dusts, marine aerosols and cooking exhausts. Results indicated that the emissions from diesel $\left(\mathrm{PM}_{10}=\sim 52 \% ; \mathrm{PM}_{2.5}=\sim 65 \%\right)$ and gasoline exhaust $\left(\mathrm{PM}_{10}=\sim 16 \% ; \mathrm{PM}_{2.5}=\sim 8 \%\right)$ vehicles are predominant sources at the study site. The emissions from cooking $\left(\mathrm{PM} 10=\mathrm{PM}_{2.5}=\sim 1.5 \%\right)$ and paved road dust $\left(\mathrm{PM}_{10}=\mathrm{PM}_{2.5}=\sim 2.3 \%\right)$ are found to be low. Presence of marine aerosols and brake wear dusts in $\mathrm{PM}_{10}$ and $\mathrm{PM}_{2.5}$ are found to be in trace quantities. Further modeling results demonstrated that diesel and gasoline emission contributions are also comparable with emission inventory results.

Another public transport source of air pollution is given by subway railway stations. High levels of particles have been found at subway and underground railway stations: the levels of $\mathrm{PM}_{10}$ and $\mathrm{PM}_{2.5}$ at a subway station in Stockholm that were 5-10 times higher than on a busy street. It is estimated that the emission factors were found to be in the range $0.2-3 \mathrm{~g} \mathrm{train}^{-1} \mathrm{~km}^{-1}$ [33].

The combustion of coal for electricity and heat production contributes to the emissions of primary particles but also formation of secondary aerosols, from the derived reactions of sulphur dioxide $\left(\mathrm{SO}_{2}\right)$ and nitrogen oxides $\left(\mathrm{NO}_{\mathrm{x}}\right)$ species to sulphate and nitrate. The critical period of air pollution is during winter, due to the long-lasting periods of high pressure, that are often accompanied by a state of thermal inversion that promote the accumulation of pollutants in the lower atmospheric layers. The amount and composition of the primary emissions are efficiently registered by various types of Air Pollution Emission Control Devices for Stationary Sources. Still the amount of emissions resulted from the local residential units or local activities remain under question due to the lack of accurate information.

Along with the burning of waste (as is $[15,34,35,36]$ or pre-treated [37, $15,38,39]$ ) or primary fossil fuels, emissions associated with the extraction work quarries is a major source of particulate matter (aspects perceived also from the population [40]). The Life Cycle Assessment inventory can give an insight on the 
estimate amount of primary emissions by type of extraction. Still the lack of data inventory delays the implementation of a PM reduction strategy in this sector.

\section{Strategies for $P M$ reduction}

The aim of the present research is to analyze a set of strategic solutions for the PM reduction without reducing the consumption of resources that plays a direct action (e.g., fuel substitution, the renewal of an automotive park, etc.) or limiting the energy consumption by acting indirectly (e.g. condensing boilers, solar panels, etc). The two strategies pose a long-term goal for which an assessment of the results can be made only after a few years of implementation.

An immediate possibility is represented by the removal of dust already present in the atmosphere (for example, through the washing of the roads) or the limits imposed during periods of criticality. In current investigations, the street sweeping combined with washing activities found a decrease of $7-10 \%$ and up to $24 \%$ in the ambient $\mathrm{PM}_{10}$ re-suspension from paved roads [41,42]. These measures are potentially easy to apply and their effectiveness is immediately evaluated. However Langston et al., [43] showed that the immediate effects on emissions reduction at urban areas where the number of the streets treated can be low. Amato et. al., suggests the street washing investigations on wider areas (some $\mathrm{km}^{2}$ ) in order to increase the absolute emission benefit.

It should be recognized that the pollutants involved are many; in fact, the contribution that the secondary particles on the total presence in the atmosphere is probably high, although studies are still in the investigation process.

Summarizing up the stationary power plants case the next measures for the particle emissions reduction are presented:

- rehabilitation of the present combustion wood plants and their transition on natural gas cogeneration sites.

- use of electrostatic precipitators for wood-fired applications are known already marketed for large systems, where the Swiss Federal Institute for Materials Testing, has successfully tested an electro cheap for fireplaces, wood stoves, pellets smaller than $30 \mathrm{~kW}$, which reduces emissions from the combustion of wood 80 to $90 \%$ [28].

- retrofitting diesel and fuel oil.

- use of condensing boilers can improve the seasonal average efficiency of production and its applicable to all installations with fan. The temperature of exhaust gases from the traditional installations varies between $120^{\circ} \mathrm{C}$ and $140^{\circ} \mathrm{C}$; lowering this value it is possible to recover about $1 \%$ of the low heating value for each $20^{\circ} \mathrm{C}$ reduction in temperature.

- use of solar panels are suggested by Taha, [44]: solar systems of up to $2 \mathrm{MW}$ should be installed on the roofs of warehouses, parking lot structures, schools, 
and other commercial buildings throughout the state; solar energy projects of up to $20 \mathrm{MW}$ in size should be built on public and private property.

- use of diesel fuel with low sulfur content - this simple strategy indicates the replace of fuel rich in sulfur with the low sulfur content as required by legislation thereby lowering the emission factor. Without reducing consumption the reduction of $\mathrm{SO}_{\mathrm{x}}$ emissions can be significant.

- use of biodiesel in power plants is highly recommended not only for $\mathrm{PM}_{10}$ reduction but mostly for the inhibition of secondary reaction with gas precursors formation and in particular on $\mathrm{SO}_{\mathrm{x}}$.

In the transport case, the long term and seasonal measures proposed for PM reduction are:

- replacement of the heavy emitting aging vehicles- the abatement of transport emissions by renewing the vehicle park (Euro 5 for light duty vehicles, Euro 6 for heavy duty vehicles) is essential.

- replacement of diesel vehicles with natural gas or Liquid Petroleum Gas(LPG)- the main benefits of LPG are that it yields $50 \%$ less $\mathrm{CO}, 40 \%$ less $\mathrm{HC}, 35 \%$ less $\mathrm{NO}_{\mathrm{x}}$ and has 50\% less OFP (ozone forming potential) compared to gasoline. LPG is also free of particulates, the main pollutant of diesel and GDI engines [45].

- use of fuels with low sulfur content already impose by Directive 2003/17/EC with $<50$ ppm sulfur. Overmore biodiesel differs from petro-diesel due to its zero or ultralow natural sulphur content, it contains no aromatic or polyaromatic hydrocarbons, it has a higher cetane value, a lower heating value, better lubricity, higher viscosity, and a higher flash point.

- use of particulate filters on diesel engines can reduce more than $90 \%$ of the particulate emissions resulted.

- traffic alternate plates: the methods consist in blocking all vehicles bearing license plates with an even number on even days and odd-odd days. It is estimated that this measure, taken into consideration all the powers that are granted (buses, motorcycles, often commercial vehicles) might cause a reduction in the daily traffic of about $15 \%$ from the theoretical point of view.

- block traffic for the most heavy emitting aging vehicles- unlike alternate plates that measure is more focused as "hits" category of vehicles responsible for the majority of emissions from transport.

- speed moderation on the highway as strategy from PM reduction can be associate with the reduction of fuel consumption. In order to obtain concrete results, it must have an extension of time adequate. It does not seem a problem to apply a limit of $90 \mathrm{~km} / \mathrm{h}$ for a few miles of highway) in winter period since the loss of time caused is very limited. The COPERT program correlates the emissions of $\mathrm{CO}_{2}, \mathrm{THC}$ and $\mathrm{CO}$ for all vehicles. In earlier 
studies and simulations with COPERT program of the traffic flow and particle emissions produced it was observed a visible reduction of air pollution due to reduction of the speed mainly on highways. To this concern a recent innovative project on integrated monitoring by low cost sensors on the territory [46] has been proposed also for an enhanced management of the speed on an Italian highway.

- improvement of public transportation infrastructures and services (e.g. optimization of MSW collection system [47, 48]).

In the extraction work area, there might be the use of special spray to wet the area of the quarry and precipitate particles dispersed in the atmosphere during the work of extraction and transit of heavy vehicles in the area. In this sense there is not yet enough data to assess the actual effectiveness of this intervention: waiting for any new knowledge it was decided not to carry out calculations for this measure.

\section{Discussion and developments}

The choice of the PM reduction actions should be based on an 'appropriate technology concept' in terms of potential for prevention and reduction of PM, their applicability and their cost compared to the benefits brought in terms of emissions avoided.

On the contrary, typical situation decision makers have to face with concerns the absence of a quantification of the ratio cost-benefits for the area where they should activate an air quality action plan.

In reality, for most of the listed options the ratio Euro to be paid per $\mathrm{kg}$ of PM avoided can be assessed referring to the primary particulate. A similar ratio for secondary particulate is more difficult to be proposed as the reactions generating it are very complex.

An additional aspect to be taken into account is the presence of incentives that can affect the calculations: the difference between gross and net costs should be pointed out.

Moreover, a significant problem to be solved is the understanding of the viability of some actions: a limitation of the vehicle circulation has a reduced effect is no control is performed.

Other strategies show a high variability in results, as street washing.

The investigation of certain types of campaigns is logistically complex for researchers without the involvement of local authorities. To this concern in many European countries significant examples of collaboration among research institutions and administrative bodies (as environmental protection agencies) can be found also supported by EU funds. 


\section{R E F E R E N C E S}

[1]. R. Vecchia, G. Marcazzana, G. Vallia, M. Ceriania, C. Antoniazzia, "The role of atmospheric dispersion in the seasonal variation of $\mathrm{PM}_{1}$ and $\mathrm{PM}_{2.5}$ concentration and composition in the urban area of Milan (Italy)". Atmos. Environ., vol. 38, 2004, pp. 44374446.

[2]. G. Hoek, B. Forsberg, M. Borowska, S. Hlawicza, E. Vaskovi, H. Welinder, M. Branis, I. Benes, F. Kotesovec, L.O. Hagen, J. Cyrys, M. Jantunen, W. Roemer, B. Brunekreef, "Wintertime $\mathrm{PM}_{10}$ and Black Smoke concentrations across Europe: results from the Peace study". Atmos. Environ., vol. 31, n. 21, 1997, pp. 3609-3622

[3]. F. Amato, X. Querol, C. Johansson, C. Nagl, A. Alastuey, "A review on the effectiveness of street sweeping, washing and dust suppressants as urban PM control methods". Sci. Total Environ., vol. 408, 2010, pp. 3070-3084.

[4]. H. Kan, R. Chena, S.Tong, "Ambient air pollution, climate change, and population health in China". Environ. Int., vol. 42, 2012, pp. 10-19.

[5]. A. Makria, N.s I. Stilianakisa, "Vulnerability to air pollution health effects", Int. J. Hyg. Environ Heal, vol. 211, nr. 3-4, 2008, pp. 326-336.

[6]. X. Querol, A. Alastuey,T. Moreno, M.M. Viana, S. Castillo , J. Pey, S. Rodríguez, B. Artiñano, P. Salvador, M. Sánchez, S. Garcia Dos Santos, M.D. Herce Garraleta, R. Fernandez-Patier, S. Moreno-Grau, L. Negral, M.C. Minguillón, E. Monfort, M.J. Sanz, R. Palomo-Marín, E. Pinilla-Gil, E. Cuevas, J. De la Rosa, A. Sanchez de la Campa, "Spatial and temporal variations in airborne particulate matter $\left(\mathrm{PM}_{10}\right.$ and $\left.\mathrm{PM}_{2.5}\right)$ across Spain 1999- 2005”, Atmos Environ, vol. 42, n.17, 2008, pp. 3964-79.

[7]. T.F. Mar, G.A. Norris, J.Q. Koenig, T.V. Larson, "Associations between air pollution and mortality in Phoenix, 1995-1997”. Environ Health Persp., vol. 108, 2000, pp. 347-353.

[8]. B.D. Ostro, S. Hurley, M.J. Lipsett, "Air pollution and daily mortality in the Coachella Valley, California: a study of PM10 dominated by coarse particles". Environ. Res., vol. 81, 1999, pp. 231-238.

[9]. A. Alastuey, T. Moreno, M.M. Viana, S. Castillo , J. Pey, S. Rodríguez, B. Artiñano, P. Salvador, M. Sánchez, S. Garcia Dos Santos, M.D. Herce Garraleta, R. FernandezPatier, S. Moreno-Grau, L. Negral, M.C. Minguillón, E. Monfort, M.J. Sanz, R. PalomoMarín, E. Pinilla-Gil et al, "Spatial and temporal variations in airborne particulate matter $\left(\mathrm{PM}_{10}\right.$ and $\left.\mathrm{PM}_{2.5}\right)$ across Spain 1999- 2005”, Atmos Environ, vol. 42, n.17, 2008, pp. 3964-79.

[10]. L. Perez, A. Tobias, X. Querol, J. Pey, A. Alastuey, J. Díaz, J. Sunyer, "Saharan dust, particulate matter and cause-specific mortality: A case-crossover study in Barcelona (Spain)", Environ. Intern., vol. 48, 2012, pp. 150-155.

[11]. L. Perez, A. Tobias, X. Querol, N. Künzli, J. Pey, A. Alastuey, M. Viana, N. Valero, M. Gonzales-Cabre, J. Suney "Coarse particles from Saharan dust and daily mortality", Epidemiology, vol. 19, n. 6, 2008, pp. 800-7.

[12]. Web site source: http://ec.europa.eu/environment/air/quality/standards.htm

[13]. R. Esworthy, "Air Quality: EPA's 2013 Changes to the Particulate Matter (PM) Standard”, Congressional Research Service 7-5700, n. R42934, 2013, p. 6.

[14]. B. Srimuruganandam, S. Nagendra, "Source characterization of PM10 and PM2.5 mass using a chemical mass balance model at urban roadside", Sci Total Environ., vol. 433, 2012, pp. 8-19. 
[15]. Ragazzi, M., Rada, E.C., "Multi-step approach for comparing the local air pollution contributions of conventional and innovative MSW thermo-chemical treatments", Chemosphere, vol. 89, nr. 6, 2012, pp. 694-701.

[16]. S. Ciuta, M. Schiavon, A. Chistè, M. Ragazzi, E.C. Rada, M. Tubino, A. Badea, T. Apostol, "Role of feedstock transport in the balance of primary PM emissions in two case-studies: RMSW incineration vs. sintering plant". Sci. Bull. Mechan Eng., series D, vol. 74, nr. 1, 2012, pp. 211-218.

[17]. Ionescu G., Zardi D., Tirler W., Rada E.C., Ragazzi M., "A critical analysis of emissions and atmospheric dispersion of pollutants from plants for the treatment of residual municipal solid waste", Sci. Bull. Mechan Eng, Series D, vol. 74, nr. 4, 2012, pp. 227-240.

[18]. J. Kukkonena, M. Pohjolaa, R.S. Sokhib, L. Luhanab, N. Kitwiroonb, L. Fragkoub, M. Rantamäkia, E. Bergec, V. Ødegaardd, L.H. Slørdale, B. Denbye, S. Finardif, "Analysis and evaluation of selected local-scale $\mathrm{PM}_{10}$ air pollution episodes in four European cities: Helsinki, London, Milan and Oslo", Atmos Environ, vol. 39, n. 15, 2005, pp. 2759-2773.

[19]. A. Răducanu, E. Codorean, C. Grigoriu, A. Meghea, "Physical chemical characteristics of power plant emissions and their impact on human health", Sci. Bull. Chem Material Sci., series B, vol. 73, nr. 2, 2011, pp. 115-122.

[20]. X. Querol, A. Alastuey, M.M. Viana,S. Rodriguez, B. Artiñano, P. Salvador, S. Garcia do Santos, R. Fernandez Patier, C.R. Ruiz, J. de la Rosa, A. Sanchez de la Campa, M. Menendez, J.I. Gil, "Speciation and origin of $\mathrm{PM}_{10}$ and $\mathrm{PM}_{2.5}$ in Spain", J Aerosol Sci, vol. 35, n.9, 2004, p.1151-72.

[21]. X. Querol, A. Alastuey,T. Moreno, M.M. Viana, S. Castillo, J. Pey, S. Rodríguez, B. Artiñano, P. Salvador, M. Sánchez, S. Garcia Dos Santos, M.D. Herce Garraleta, R. Fernandez-Patier, S. Moreno-Grau, L. Negral, M.C. Minguillón, E. Monfort, M.J. Sanz, R. Palomo-Marín, E. Pinilla-Gil et al, "Spatial and temporal variations in airborne particulate matter $\left(\mathrm{PM}_{10}\right.$ and $\left.\mathrm{PM}_{2.5}\right)$ across Spain 1999- 2005”, Atmos Environ., vol. 42, n.17, 2008, pp. 3964-79.

[22]. C. Misra, M.D. Geller, P. Shah, C. Sioutas, P.A. Solomon, "Development and evaluation of a continuous coarse $\left(\mathrm{PM}_{10}-\mathrm{PM}_{2.5}\right)$ particle monitor". J Air Waste Manage. Assoc., vol. 51, 2001, pp. 1309-1317.

[23]. K. Cheung, N. Daher, W. Kam, M.M. Shafer, Z. Ning, J.J. Schauer, C. Sioutas, Spatial and temporal variation of chemical composition and mass closure of ambient coarse particulate matter $\left(\mathrm{PM}_{10-2.5}\right)$ in the Los Angeles area, Atmos Environ., vol. 45, 2011, pp. 2651-2662.

[24]. M. Sillanpää, R. Hillamo, S. Saarikoski, A. Frey, A. Pennanen, U. Makkonen, Z. Spolnik, R. Van Grieken, M. Branis, B. Brunekreef, M.C. Chalbot, T. Kuhlbusch, J. Sunyer, V.M. Kerminen, M. Kulmala, R.O. Salonen, "Chemical composition and mass closure of particulate matter at six urban sites in Europe", Atmos Environ., vol. 40, 2006, pp. $212-223$.

[25]. C. Hueglin, R. Gehrig, U. Baltensperger, M. Gysel, C. Monn, H. Vonmont, "Chemical characterisation of $\mathrm{PM}_{2.5}, \mathrm{PM}_{10}$ and coarse particles at urban, near-city and rural sites in Switzerland", Atmos Environ., vol. 39, 2005, pp. 637-651.

[26]. D. Hjortenkrans, B. Bergbäck, A. Häggerud, "New metal emission patterns in road traffic environments", Environ Monit Assess, vol. 117, 2006, pp. 85-98.

[27]. A.P. Davis, M. Shokouhiian, S. Ni, "Loading estimates of lead, copper, cadmium, and zinc in urban runoff from specific sources", Chemosphere, vol. 44, 2001, pp. 997-1009.

[28]. E.C. Rada, M. Ragazzi, E. Malloci, "Role of levoglucosan as a tracer of wood combustion in an alpine region", Environ Technol., vol. 33, n. 9, 2012, pp. 989-994. 
[29]. J.P. Putaud, F. Raes, R. Van Dingenen, E. Brüggemann, M.C. Facchini, S. Decesari, S. Fuzzi, R. Gehrig, C. Hüglin, P. Laj, G. Lorbeer, W. Maenhaut, N. Mihalopoulos, K. Müller, X. Querol, S. Rodriguez, J. Schneider, G. Spindler, H. ten Brink, K. Tørseth, A. Wiedensohler, "A European aerosol phenomenology-2: chemical characteristics of particulate matter at kerbside, urban, rural and background sites in Europe", Atmos Environ., vol. 38, 2004, pp. 2579-2595.

[30]. K. Juda-Rezlera, M. Reizera, J.P. Oudinetb, "Determination and analysis of PM10 source apportionment during episodes of air pollution in Central Eastern European urban areas: The case of wintertime 2006", vol. 45, n. 36, 2011, pp. 6557-6566.

[31]. P. Aarnio, J. Martikainen, T. Hussein, I. Valkama, H. Vehkamäki, L. Sogacheva, J. Härkönen, A. Karppinen, T. Koskentalo, J. Kukkonen, M. Kulmala, "Analysis and evaluation of selected $\mathrm{PM}_{10}$ pollution episodes in the Helsinki Metropolitan Area in 2002", Atmos Environ., vol. 42, n. 17, 2008, pp. 3992-4005.

[32]. M. Koçaka, N. Mihalopoulosb, N. Kubilaya, "Contributions of natural sources to high $\mathrm{PM}_{10}$ and $\mathrm{PM}_{2.5}$ events in the eastern Mediterranean”, Atmos Environ., vol. 41, n. 18, 2007, pp. 3806-3818.

[33]. E. Fridella, M. Ferma, A. Ekbergb, "Emissions of particulate matters from railways Emission factors and condition monitoring", Transport Res. Part D: Trans. Env, vol. 15, 2010, pp. 240-245.

[34]. M. Ragazzi, M, Grigoriu, E.C. Rada, E. Malloci, F. Natolino, "Health risk assessment from combustion of sewage sludge treatment: three caste study comparison”, Proceedings of the Internationl Conference on Risk Management, Assessment and MitigationRIMA'10, 2010, pp.176-180

[35]. E.C. Rada, I. A. Istrate, M. Ragazzi, "Trends in the management of the Residual Municipal Solid Waste”, Environ Technol., vol. 30, nr. 7, 2009, pp. 651-661.

[36]. M. Ragazzi, E.C. Rada, "Effect of recent strategies of selective collection on the design of municipal solid waste treatment plants in Italy", WIT Transactions on Ecology and the environment, vol. 109, 2008, pp. 613-620.

[37]. M. Ragazzi, E.C. Rada, "RDF/SRF evolution and MSW bio-drying", WIT Transactions on Ecology and Environment, vol. 163, 2012, pp. 199-208.

[38]. E.C. Rada, M. Ragazzi, T. Apostol, "Role of Refuse Derived Fuel in the Romanian industrial sector after the entrance in EU", WIT Transactions on Ecology and Environment, vol. 109, 2008, pp. 89-96.

[39]. E.C. Rada, M. Ragazzi, V. Panaitescu, T. Apostol, "Some research perspectives on emissions from bio-mechanical treatments of municipal solid waste in Europe", Environ Technol., vol. 26, n. 11, 2005, pp. 1297-1302.

[40]. C. di Mauro, S. Buochon, V. Torretta, "Industrial risk in the lombardy region (Italy): What people perceive and what are the gaps to improve the risk communication and the participatory processes", Chem Eng Transaction, vol. 26, pp. 297-302.

[41]. F. Amato, X. Querol, A. Alastuey, M. Pandolfi, T. Moreno, J. Gracia, Rodriguez, "Evaluating urban $\mathrm{PM}_{10}$ pollution benefit induced by street cleaning activities", Atmos Environ., vol. 43, n. 29, 2009, pp. 4472-4480.

[42]. C.M. Chou, Y.M. Chang, W.Y. Lin, C.H. Tseng, L. Chen, "Evaluation of street sweeping and washing to reduce ambient $\mathrm{PM}_{10}$, Int J Environ Pollut., vol. 31, n. 3-4, 2007, pp. 431-438.

[43]. R. Langston, R.S.J. Merle, D. Hart, V. Etyemezian, H. Kuhns, H. Gillies, D. Fitz, K. Bumiller, D.E. James, "The preferred alternative method for measuring paved road dust emissions for emissions inventories: mobile technologies vs. The traditional ap-42 methodology". Prepared for EPA OAQPS, March, 2008, pp. 110. 
[44]. H. Taha, "The potential for air-temperature impact from large-scale deployment of solar photovoltaic arrays in urban area", Solar Energy, 2012, http://dx.doi.org/10.1016/j.solener.2012.09.014.

[45]. C.L Myun, K. Choi, J. Kim, Y. Lim, J Lee, S. Park, "Comparative study of regulated and unregulated toxic emissions characteristics from a spark ignition direct injection light-duty vehicle fueled with gasoline and liquid phase LPG (liquefied petroleum gas)“, Energy, vol. 44, 2012, pp. 189 - 196.

[46]. E.C. Rada, M. Ragazzi, M. Brini, L. Marmo, P. Zambelli, M. Chelodi, M. Ciolli, "Perspectives of low-cost sensors adoption for air quality monitoring". Sci Bull. Mechan Eng. vol. 74, serie D, n. 2, 2012, pp. 243-250.

[47]. E.C. Rada, M. Grigoriu, M. Ragazzi, P. Fedrizzi, "Web oriented technologies and equipments for MSW collection", Proceedings of the International Conference on Risk Management, Assessment and Mitigation - RIMA '10, 201, pp. 150-153

[48]. V. Torretta V., E.C. Rada, V.N. Panaitescu, T. Apostol "Some considerations on particulate generated by traffic, Sci Bull. Mechan Eng., vol. 74, serie D, n. 4, 2012, pp. 141-148. 